\title{
Establishment of the Liaison Mechanism for Party Construction of State-Owned Commercial Banks
}

\author{
Chuangqiang $\mathrm{Xu}^{1} \&$ Qingxiang Feng ${ }^{2}$ \\ ${ }^{1}$ School of Marxism, Central University of Finance and Economics, Beijing, China \\ ${ }^{2}$ The Center for Studies of Hong Kong Macao and Pearl River Delta, Sun Yat-sen University, Guangzhou, China \\ Correspondence: Qingxiang Feng. E-mail:fengqx8@mail.sysu.edu.cn
}

Received: June 1,2020 Accepted: June 25, $2020 \quad$ Online Published: June 29, 2020

doi:10.5539/ass.v16n7p141 URL: https://doi.org/10.5539/ass.v16n7p141

\begin{abstract}
Business operation and the construction work of the Communist Party of China (hereinafter referred to as the Party or CPC) are organically connected for state-owned commercial banks. It's of great importance and value for transformation and progress of the sate-owned commercial banks to improve the liaison mechanism for party construction of the state-owned commercial banks, facilitate efficient interaction among the party organizations at all levels of the state-owned commercial banks and good communication among the party members, break the information isolated island among the party organizations at all levels of the state-owned commercial banks, and establish a convenient and fast communication network. Thus, an interlinking mechanism for party construction of the state-owned commercial banks should be built. Measures should be taken to build closer relationship between the Party and the masses, between the cadres and the masses; and further improve the humanistic care mechanism of the party organizations of the state-owned commercial banks.
\end{abstract}

Keywords: state-owned commercial banks, party construction; Liaison mechanism; network-based interaction; communication

\section{Introduction}

The financial industry is a lifeline for sustained and stable development of the national economy, and the state-owned commercial banks are the major players. Sticking to leadership of the Communist Party of China (hereinafter referred to as the Party or CPC) ensures healthy development of the state-owned commercial banks. The operating mechanism for party construction manifests the political strengthens of Chinese state-owned commercial banks. With such a mechanism, the banks can serve as a model for other state-owned financial enterprises with regard to party construction. In the new era, the integrated mechanism for party construction of Chinese state-owned commercial banks contains the links of operation, incentive, restriction, liaison, guarantee, etc.; exists throughout the leadership and guidance of the Party Central Committee toward the state-owned commercial banks; and effectively ensures orderly operation of the party organizations at all levels of the state-owned commercial banks. Longitudinally, the party system of the state-owned commercial banks is composed of the party organizations at all levels in the headquarter, branches and sub-branches. Vertically, the party system of the state-owned commercial banks constitutes of the party groups of all departments. The staff who are party members are the most important and most vigorous elements of party construction of the state-owned commercial banks. It's of great importance and value for transformation and progress of the sate-owned commercial banks to improve the liaison mechanism for party construction of the state-owned commercial banks, facilitate efficient interaction among the party organizations at all levels of the state-owned commercial banks and good communication among the party members, break the information isolated island among the party organizations at all levels of the state-owned commercial banks, and establish a convenient and fast communication network.

\section{Point of View}

\subsection{Establishing an Interlinking Mechanism for Party Construction of the State-Owned Commercial Banks}

When conducting the party construction work, the vertical communication is blocked. Firstly, the top-down communication is ineffective. The superior branch, in some occasions, could not fully understanding the party construction needs of the sub-branches. The policies or strategies passed on to the sub-branches by the superior 
branch are not applicable. Secondly, the bottom-up communication is ineffective. The sub-branches could not fully understand the messages conveyed by the superior branch through the party construction activities and have insufficient knowledge of the significance of party construction activities. Some party members' suggestions and opinions cannot be delivered to the management of the sub-branch or the headquarter. Thus, they can hardly build a democratic atmosphere among the party or Giza actions or enhance vitality of party construction. The longitudinal communication within the party network is relatively weak. On the one hand, the communication among all relevant departments of the state-owned commercial bank is inadequate. They do not have many chances for mutual learning and interchange, and lack the senses of competition and cooperation. On the other, the party organizations have insufficient communication and coordination with the business departments. The business departments are busy with their work tasks and pay less attention to the general goal of the bank and party construction. There lacks collaboration and mutual supervision.

Now, it's essential to improve the longitudinal and vertical communication, strengthen communication among relevant departments and the party organizations and develop an interlinking mechanism for party construction. A series of liaison mechanisms between the masses and the party members, among party members, between party members and the party organization, between the internal party organizations and party organizations of other entities should be built. Communications and mutual learning among different departments and party organizations at all levels should be facilitated. Successful experience and constructive suggestions should be carefully learned to lay a solid foundation for improvement of the party construction of state-owned commercial banks.

Firstly, leaders of the party organizations at all levels should attend the party meetings of the sub-branches and the party classes; should communicate with the party members, help them with their problems and concerns, thus to build closer relationship between the cadres and the masses. Secondly, the party organizations of the sub-branches should cooperate with the party organizations of the communities and other public institutions and enterprises; should establish the work and communication mechanism, organize regular exchange and mutual facilitation activities and events from time to time, thus to draw new perspectives and insights for party construction work and facilitate bank-enterprise cooperation. Deepening state-owned commercial bank reform does not mean to halt the party construction work. The personnel engaged in party construction work should improve the party construction administration regulation through institutional innovation, make full play of their supervisory role in all decision-making and execution processes, and highlight the core values of Chinese socialism and make it the ideological and political core of the state-owned commercial banks. Thirdly, the content and method of party construction work and should be improved based on the concrete situation. The work mechanism should be optimized to make it better adapt to the time and raise efficiency of party construction. Last but not the least, the work mechanism for party construction should be improved through innovative ways. There should be a sound ideological and political education system for the staff to guide them correctly understanding reform, help them deal with ideological problems with regard to role change after reform, and give full play to the leading role of the state-owned commercial banks in party construction. Facing the new situation, the state-owned commercial banks should integrate resources, optimize internal structure of the party organizations, change the existing problem, that is, good policy/strategy, but poor implementation. Through party construction, the state-owned commercial banks should help the sub-branches with risk management in daily operation. Starting from institutional design, the state-owned commercial banks should change the assessment system, encourage the sub-branches to reveal and disclose risks so as to solve them at an early stage, provide positive guidance for management and assessment, strengthen the liaison mechanism for party construction to realize efficient communication/linkage of information, personnel and different organizations.

\subsection{Building Closer Ties between the Party and the Masses, Between the Cadres and the Masses}

According to the Decision deliberated and adopted at the Fourth Plenary Session of the 19th Central Committee of the CPC, the CPC should implement the mass line strategy, improve the system for the party members and cadres better communicate with the masses, and establish a new Internet-based masses work mechanism. The CPC should serve the masses, trust the masses, depend on the masses, lead the masses, join the masses and go down to the primary organizations (Central Committee of the CPC, 2019). Building closer ties between the party and the masses, between the cadres and the masses comply with the tenet and nature of CPC and is part of the work to systematically building the bridges and bonds between $\mathrm{CPC}$ and the masses. As a major part of the party construction work, improving relations between the party and the masses, between the cadres and the masses is beneficial for strengthening the mass foundation of the party, consolidate the governing status of $\mathrm{CPC}$, and should be considered as the new behavior of the party organizations of the state-owned commercial banks in the new era. 
Sticking to the leadership of CPC is the guarantee for deepening reform and promoting transformation of the state-owned commercial banks. It's not only the requirement but also the advantage of the state-owned commercial banks to develop closer ties between the party and the masses, between the cadres and the masses. The state-owned commercial banks have a large number of primary party organizations. The party members work at different branches/sub-branches and different posts. In order to drive the state-owned commercial banks marching along the route in line with the strategic arrangement of the CPC Central Committee, it's essential to strengthen the core leadership of the Party and arouse enthusiasm and gain support of the masses. Therefore, it's vital to establish close ties between the Party and the masses, between the cadres and the masses; give full play to the fortress function of the primary party organizations, and build sound communication mechanism with the work union. In the new situation, measures should be taken to encourage coordination cadres and the ordinary party members, make them play the maximum role at all positions, and help them keep enhancing their capability to better serve the masses, thus to demonstrate the responsibility of the state-owned enterprises.

Party organizations at all levels of the state-owned commercial banks should implement President Xi Jinping's important thought on the primacy of the people, stick to the mass line strategy, carry out mass-related work well, intensify the Party-masses and cadre-masses communication mechanism, and guide the staff to participate in democratic management, democratic supervision and democratic decision-making process.

In the process of establishing the systems directly related to the staff's benefits, such as salary and welfare, attendance and vacation, professional code for conduct, voices of different personnel should be taken into consideration. A sound internal interests coordination mechanism should be created. Decisions should be made in a scientific and democratic manner to offer strong guarantee for the state-owned enterprises' stability, harmony and reform. Party organizations at all levels should stick to the tenet of serving the people wholeheartedly, and should always believe that the people are the sources of strength. The party members should visit the staff's families on a regular basis to learn their life and their families, and gain a knowledge of the most urgent problems faced by the staff. The model role of cadres should be given into full play. Activities should be organized to help the masses and convey the Party culture. Sponsorship of non-profit foundations or support of talent teams should be used to drive sustainable development of the mass organizations, federations of women and for protection of the elderly and the children, and organizations of the youth. Measures should be taken to motivate initiative, enthusiasm and creativity of the masses, facilitate effective communication between the party cares/members and the masses, and develop a cohesive force for developing a better life. In this way, the state-owned commercial banks will accumulate a strong social support for their long-term development.

\subsection{Improving Humanistic Care Mechanism of the Party Organizations of State-Owned Commercial Banks}

The staff who are party members are the most energetic in the state-owned commercial banks. Their work attitude and mental status directly concern operational efficiency and prospect of the banks. By optimizing the humanistic care mechanism of the party organizations, the state-owned commercial banks can better meet the spiritual and cultural demands of the party members, and help the party members effectively manage their emotions and maintain mentally healthy development.

President Xi Jinping once said that a strict system for daily education and management of the party members should be established; and the party members should fully play the model role and be able to discover the problems in the daily work, willing to stand out at critical moments, and have the courage to take the lead or even sacrifice at stake (Xi Jinping, 2017). At current stage, after several rounds of innovative reform, the state-owned commercial banks have made great breakthroughs in the party construction work at primary level. Enthusiasm and initiative of the party members at primary party organizations have been effectively aroused, and they are more willing to contribute to the party construction work. In spite of the achievements, there are still problems. A distinction between the important and the lesser ones should be made. The practical situation of the bank and urgent needs of the party members and masses should always be considered in the reform and party construction. Close attention should be paid to the mental and practical problems of the staff. Solving the prominent problems should be regarded as the final goal. Only in this way, can the party organizations help improve the staff's status and alleviate their pressure. Only in this way, can they help the staff perform better at their work and the party members strengthen their deal and belief. Only in this way, can the party construction work gain practical significance.

To improve the humanistic care mechanism of the party organizations of state-owned commercial banks, measures could be taken from the following aspects.

First, the party organizations should show their care and warmth to the party members and cares and help them with their problems and difficulties. In this changing world, the social development is getting diversified and the 
value orientation is getting pluralistic. All collisions, conflicts and changes coming with the time constantly influence the party members in various methods from various perspectives. What they face now are the standards, role expectations, lifestyle and code of conduct which have changed and are now still changing. Therefore, the primary party organizations of the state-owned commercial banks should show care and support to the party members for their work, life and mental health; should emphasize humanistic care and psychological counseling, and intensify care for the party members through various ways, such as visit, talk, partner assistance, psychological assistance and inner-party assistance fund. Those in charge of party construction at primary level should show their care to the staff from time to time, talk with them, stick to the concept and principle of "from the masses, to the masses", learn the masses' difficulties, and create a harmonious, warm, united and positive atmosphere.

Second, secretaries of the primary party organizations at all branches/sub-branches of the state-owned commercial banks should play the model and leading role. They should talk to the young party members, organize communication activities, try to develop a fixed mechanism, remove all barriers in communication, encourage the staff to work practically, keep improve themselves in work, help the party members with their concerns and problems, fully protect rights and legitimate interests of the party members, and cultivate new force for developing the party organizations of state-owned financial enterprises.

Third, more and better platforms for mutual learning and exchange should be created for the party members and staff of the state-owned commercial banks. They should be built into "study-oriented banks" to continuously cultivate talents; make talent development planning, strengthen talent training, help the staff with the development director and help the party members make career development plan; keep enhancing the professional capacity and professional ethics of the party members and the staff; and organize themed activities demonstrating the culture of $\mathrm{CPC}$ to enrich the cultural life of the state-owned commercial banks' party members.

Lastly, the role of party construction at the primary level of the state-owned commercial banks should be given into full play. The primary party organizations should deliver humanistic care to the party members and the staff. The purpose is to help the party members to "find their career development route, enhance political accomplishment based on their work". The primary party organizations are the fortress of the party construction work. Once the party constriction work at the primary level is conducted effectively, the general governing capacity of the Party will be enhanced, and the governing position of party organizations in the state-owned financial enterprises will be consolidated.

All in all, in the party construction work, enhancing political consciousness of the party members should be regarded as the aim. Ideological and political publicity should be continuous conducted. In addition, the party organizations should make in-depth communication with the party members, learn their mental world, and provide guidance on values, nourishment for the mind, and psychological counseling to the party members. In this way, the party organizations may guide the staff using correct values and active attitude in work and daily life, help them gain the sense of achievement and success in work, and instruct them changing the happy work mode into a positive lifestyle.

\section{Conclusions}

According to President Xi Jinping, it is the major political task and work theme of the leadership of the CPC Central Committee to fully implement the spirit of the 19th Communist Party of China National Congress and try the best to realize the goals established on the 19th Communist Party of the China National Congress. The new time means new starting point and new requirement and calls for new situation and new conducts (Xi Jinping, 2018). In the new era, the state-owned commercial banks should follow the steps and respond to the call of the CPC Central Committee, improve the work mechanism for party construction, facilitate the institutional inform, mechanism restructuring, personnel optimization and transformational development of the banks, and play the due role and make due contribution to the great causes of building a well-off society in an all-round way and the great rejuvenation of China. In the new era, the integrated mechanism for party construction of Chinese state-owned commercial banks contains the links of operation, incentive, restriction, liaison, guarantee, etc.; shall exist throughout the process of integrating party construction in the governing structure of the state-owned commercial banks; and effectively support the party organizations of the headquarter, all branches and sub-branches complement with the board of directors, the board of supervisors and the management and jointly promote orderly operation of the banks. Establishing an effective liaison mechanism is essential. By establishing an interlinking work mechanism for party construction, devoting to building closer ties between the Party and the masses, between the cadres and the masses, improving the humanistic care mechanism, facilitating interactions 
among the party organizations at all levels and among the party members and the staff, the state-owned business banks can greatly improve the effectiveness and vitality of party construction.

\section{References}

Fend, B. (2012). A Study on Party Construction of Private Enterprises (pp. 128-176). BJ: Press of Communication University of China.

Li, Z. P. (2018). A Study on the Ideological and Political Work Methods of the State-owned Enterprises in the New Era (pp. 36-52). WH: Wuhan University Press.

Qiu, S. Q. (2011). On Party Construction of Modern Enterprises (pp. 56-95). SH: Shanghai People's Press.

The CCCPC. (2019). The Decision of the CPC Central Committee on Major Issues Concerning Upholding and Improving the System of Socialism with Chinese Characteristics and Advancing the Modernization of China's System and Capacity for Governance (p. 8). BJ: The People's Press.

Xi, J. P. (2017). The Governance of China II (pp. 151-216). BJ: Foreign Languages Press.

Xi, J. P. (2018). Speech on First Plenary Session of the 19th CPC Central Committee. Qiushi, (1), 1-2.

Xi, T. L., \& Chen, X. L. (2017). A Study on Innovations of Party Construction of the State-owned Enterprises. People's Forum, (21), 88-91.

Xiao, J. (2017, September 15). Exploring the Path of Party Construction of the Commercial Banks at the Primary Level. Financial Times, (10).

\section{Copyrights}

Copyright for this article is retained by the author(s), with first publication rights granted to the journal.

This is an open-access article distributed under the terms and conditions of the Creative Commons Attribution license (http://creativecommons.org/licenses/by/4.0/). 